\title{
A desconstrução do suspense na telenovela pela valorização do saber antes ${ }^{1}$
}

Luiz Antonio de Paula

Mestrando em Ciências da Comunicação na ECA-USP. Diretor dos jornais Ipiranga News $e$ Jabaquara News. Editor chefe do jornal Diário Popular (1988-1995).

E-mail: luiz.apaula@uol.com.br

A divulgação antecipada de resumos dos capítulos das telenovelas brasileiras, além de relativizar a importância do suspense para o gênero, mostrou ser possível a interação entre um produto essencialmente televisivo e outros suportes midiáticos. Tendo como pilares básicos de seu sucesso e empatia com os espectadores a criação e a manutenção de expectativas, as tramas não registraram queda na audiência com a revelação de cenas futuras. Já os meios que informam previamente as peripécias dos personagens desse mundo imaginário agregaram novos focos de atração para seu público.

Essa sinergia intermeios foi facilitada por um processo de valorização do saber antes, desenvolvido entre os telespectadores, fruto do modelo econômico globalizado. Na nova configuração de mercado, a indústria da comunicação experimentou uma série de fusões e incorporações, com as megacorporações resultantes se destacando por diversificar áreas de atuação e administrar com os mesmos conceitos veículos impressos, radiofônicos, televisivos, informáticos e de entretenimento, exigindo apenas uma relação lucrativa entre eles ${ }^{2}$. No Brasil, por existir um grupo quase monopolista no setor (as Organizações Globo), esse movimento assumiu uma diretiva peculiar: os outros grandes grupos foram obrigados a noticiar as atividades do hegemônico, ampliando a complexidade do fenômeno, tema desta análise.

Maria Immacolata Vassallo de Lopes e outras autoras registraram:

[...] a apropriação da telenovela ultrapassa a dimensão do lazer, impregnou as rotinas de vida de tal maneira que o receptor já não a percebe como opção de divertimento... A telenovela desaloja campos de interesse de jovens e crianças... Para eles é mais importante chegar à escola dominando o conhecimento dos próximos capítulos, do que dominar o conhecimento transmitido pela escola ${ }^{3}$.

1. Trabalho apresentado ao Grupo de Trabalho "Mídia e Recepção" do XV Encontro da Compós, na Unesp, Bauru-SP, em junho de 2006.

2. Sobre globalização e mídia, ver MORAES, Dênis de. A comunicação sob domínio dos impérios multimídias. In: DOWBOR, Ladislau et al. (Orgs.). Desafios da comunicação. Petrópolis: Vozes, 2000; Planeta mídia: tendências da comunicação na era global. Campo Grande: Letra Livre, 1998.

3. LOPES, Maria I. V. de et al. Vivendo com a telenovela: mediações, recepção, teleficcionalidade. São Paulo: Summus, 2002. 
4. MARTÍN-BARBERO, Jesús; REY, Germán. Os exercícios de ver: hegemonia audiovisual e ficção televisiva. Tradução de Jacob Gorender. São Paulo: Senac São Paulo, 2001. p. 115

5. O inglês Jeremy Bentham (1748-1831) fo filósofo utilitarista, economista, jurista e revolucionou os estudos dos métodos de punição, ao criar um sistema possíve de controlar presos, sem que eles soubessem esta sendo vigiados e quem os acompanhava.

6. FOUCAULT, Michel. Vigiar e punir: nascimento da prisão. Tradução Raquel Ramalhete. Petrópolis: Vozes, 1997. p. 168-169. comunicação \& educação • Ano XIII • Número 1 • jan/abr 2008

\section{TODOS GANHAM, MAS A TV GANHA MAIS}

Foi no final dos anos 1980 e início dos 1990 que se verificou o crescimento do espaço destinado a assuntos relacionados à televisão nos veículos impressos de São Paulo. No Rio de Janeiro, o jornal $O$ Globo já publicava sua Revista da TV como instrumento de divulgação das atrações da TV do grupo. Havia, na época, dúvidas sobre a validade de se publicar resumos de capítulos inéditos. Autores, profissionais de produção e os departamentos de marketing das emissoras temiam perder audiência, e editores de jornais, especialmente os que definiam seu público-alvo como classes A/B, questionavam por que alguém teria interesse em ler antecipadamente as cenas e ver quebrado o suspense no seu aspecto lúdico.

Os resultados foram estimulantes para todos e levaram à intensificação da prática e à entrada de outros meios nessa parceria. Atualmente, além dos principais jornais do País, os telespectadores encontram nas bancas diversas revistas que trazem os resumos dos capítulos. Também podem acessá-los em inúmeros sites, ouvi-los no rádio e em programas vespertinos de TV. O significativo universo atingido por tais instrumentos se amplia exponencialmente com a propagação do saber antes em conversas de pontos de ônibus, padarias, salões de cabeleireiros, escolas, escritórios etc.

Entender quem ganha com a nova maneira de o telespectador se relacionar com o ficcional, aceitando (e desejando) assistir a cenas que já lhe foram resumidas em jornais e revistas, programas de rádio e de TV e internet, é importante para avaliar como se distribuem o poder e a influência da mídia. Se a audiência mantém-se elevada, os divulgadores da antecipação ganham clientes e o público pode orgulhar-se de deter informação tão valorizada, aparentemente é uma interação em que todos se beneficiam. Porém, evidências práticas indicam que o lucro maior tem sido da televisão.

Martín-Barbero aponta esse suporte midiático como cenário para pensar nas consistências e inconsistências do público, acrescentando:

[...] o relato telenovelesco remete também à longa experiência do mercado para captar, na estrutura repetitiva da série, as dimensões ritualizadas da vida cotidiana e, juntando o saber fazer contas com a arte de contar histórias, conectar com as novas sensibilidades populares para revitalizar narrativas midiáticas gastas $[\ldots]^{4}$.

Essa constatação do pesquisador espanhol, radicado na Colômbia, leva à hipótese de que a estratégia da antecipação do desenrolar das tramas se transformou em eficiente fórmula de pesquisa, funcionando, inclusive, como uma espécie de instrumento pan-óptico, no sentido metaforizado por Michel Foucault.

Lembrando que o Pan-óptico de Bentham ${ }^{5}$ funciona como um laboratório de poder, Foucault assinala que ele: “[...] pode ser utilizado como máquina de fazer experiências, modificar o comportamento, treinar ou retreinar os indi-

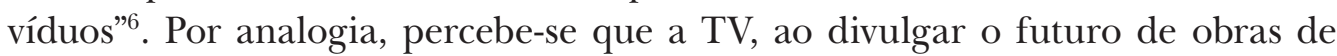
ficção, tem a oportunidade de vigiar seu público, não com o objetivo de punir, 
como na visão de Foucault, mas de atrair e avaliar suas posições. Caso emblemático aconteceu na novela América ${ }^{7}$, exibida pela TV Globo, na polêmica criada com o anúncio de que dois personagens masculinos se beijariam no capítulo final. A possibilidade gerou reações contrárias mais fortes que as favoráveis e a emissora optou por não exibir o beijo.

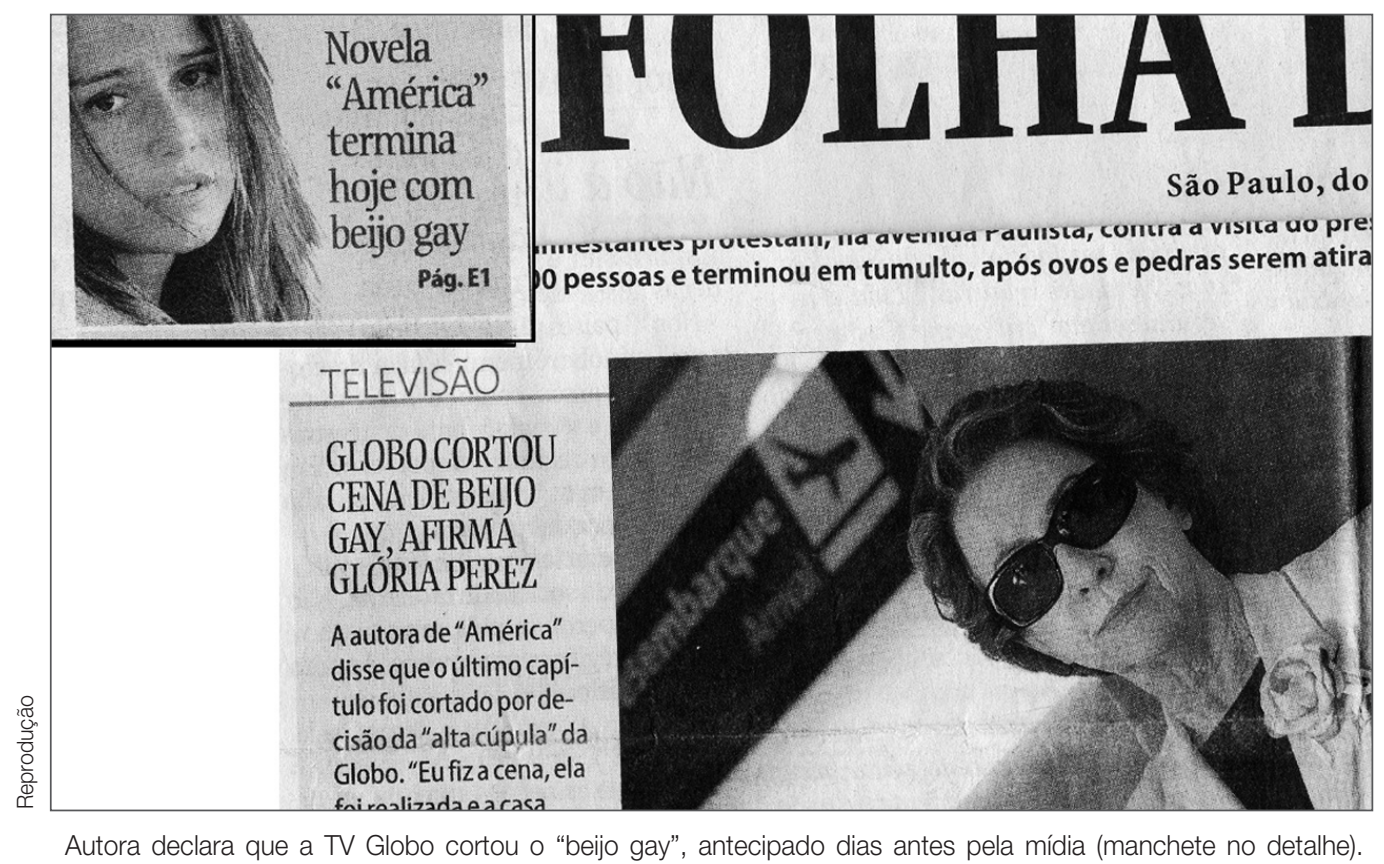

O episódio também revela o fato de a sinergia intermeios ser operada como concessão. Os capítulos são disponibilizados pelas emissoras e as fontes das pistas são os autores. Detentor da informação, o suporte televisivo se reserva o direito de não repassar o conteúdo da fase final da história e a indicação do autor pode ser só teste para avaliar a receptividade do público. Jeanne Marie Machado de Freitas usa conceitos da Escola de Frankfurt ao mostrar essa forma de revelar poder. A pesquisadora ressalta que, para o grupo de sociólogos e filósofos reunidos em torno de Theodor Adorno e Max Horkheimer, a manipulação é exercida pela chamada indústria cultural e por seus meios de produção industrial das mensagens, "porque o produto que circula - as mensagens - é fabricado e posto em circulação de maneira perfeitamente controlável".

Outra importante contribuição para se compreender o poder da televisão como técnica social é encontrada em Octavio Ianni. No ensaio O Príncipe Eletrônico, o sociólogo, falecido em abril de 2004, lembra que ela é um meio de comunicação, informação e propaganda presente e ativo no cotidiano de uns e outros, indivíduos e coletividades, em todo o mundo:

Registra e interpreta, seleciona e enfatiza, esquece e sataniza o que poderia ser a realidade e o imaginário. Muitas vezes, transforma a realidade seja em algo encantado, seja em algo escatológico, em geral virtualizando a realidade em tal escala que o real aparece como forma espúria do virtual ${ }^{9}$.
7. De Glória Perez. Direção geral de Jayme Monjardim e Marcos Schechtman, mar./nov. 2005. Monjardim deixou a novela quarenta dias após a estréia por divergências com a autora e Marcos assumiu a direção sozinho.

8. FREITAS, Jeanne Marie Machado de. Comunicação e psicanálise. São Paulo: Editora Escuta, 1992. p. 38.

9. IANNI, Otavio. O príncipe eletrônico. In: Id. Enigmas da modernidade - Mundo. Rio de Janeiro: Civilização Brasileira, 2000. p. 149-150. 


\section{NOVA DINÂMICA NO ENREDO PARA O NOVO TELESPECTADOR}

As análises de Freitas e Ianni, enquadradas em uma concepção de cenário pan-óptico, reforçam a visão de que a necessidade de a indústria cultural assegurar-se de estar satisfazendo à demanda do público se liga ao fenômeno da desconstrução do suspense nas telenovelas. A estratégia envolveu também a alteração da dinâmica dos enredos desse produto televisivo, que mantém a estrutura de sua implantação como gênero, mas assumiu ritmo mais veloz. No prefácio de Memória da Telenovela Brasileira, de Ismael Fernandes, o novelista Walter George Durst (1922-1997) assinalou:

De fato, sempre considerando os apontamentos de Ismael, a impressão final que se tem é a de que as novelas resenhadas no seu extenso guia, guardadas as diferenças de forma, afinal de contas resumem-se apenas em pouco mais de meia dúzia de entrechos paradigmáticos ${ }^{10}$.

O autor da obra avaliza o diagnóstico:

[...] para conhecer a telenovela brasileira por inteiro não é necessário ter assistido aos quase 500 títulos que fizeram esses vinte e tantos anos de dramas do dia-adia. Existe um roteiro base... Uma grande história de amor no centro, rodeada por conflitos familiares, um mistério ou um segredo que o público desconhece e os personagens não ou vice-versa $[\ldots]^{11}$.

Todos esses elementos continuam presentes, mas, atualmente, o autor precisa agradar um telespectador diferente.

Doc Comparato observa que a televisão e o cinema já foram considerados entretenimentos passivos, pela impossibilidade de o espectador refletir sobre o conteúdo da mensagem recebida devido à velocidade em que a informação era passada, mas que o termo caiu em desuso com a aparição do vídeo e do controle remoto: "[...] O zapping, quase um esporte, acabou por definir a atitude do espectador, capaz de trocar de canal de poucos em poucos minutos e de ver, até, mais de um programa de cada vez"12.

Zygmunt Bauman, criador da expressão modernidade líquida para definir os tempos globalizados em que conceitos sólidos da modernidade estão derre-

10. FERNANDES, I. Memória da telenovela brasileira. 3. ed. São Paulo: Brasiliense, 1994. p. 11.

11. Ibid., p. 22-23.

12. COMPARATO, D. Da criação ao roteiro. Rio de Janeiro: Rocco, 1995 p. 64-65

13. BAUMAN, Zygmunt. Modernidade líquida. Tradução Plínio Dentzien. Rio de Janeiro: Jorge Zahar, 2001. p. 145 tendo, destaca a nova maneira de encarar o tempo e corrobora o diagnóstico de Comparato: "[...] Não se ganha muito com considerações de 'longo prazo' [...]. O 'curto prazo' substituiu o 'longo prazo' e fez da instantaneidade o seu ideal último"13. Dentro desse panorama do imediato, o recurso usado com êxito nas tramas recordistas de audiência é criar situações episódicas, que se transformam em enredos dentro do enredo. A heroína já não sofre meses à espera do final feliz. Ela encontra diversos obstáculos que são superados em pequenos espaços de tempo.

Além disso, avaliações constantes pelo ângulo pan-óptico de auscultar o público podem alterar o perfil e o destino dos personagens. Nesse ponto, Bauman amplia as possibilidades de análise ao citar Thomas Mathiesen, para quem 
[...] a poderosa metáfora do Pan-óptico de Bentham e de Foucault não dá conta dos modos em que o poder opera. Mudamos-nos, agora, sugere Mathiesen, de uma sociedade do estilo Pan-óptico para uma sociedade do estilo sinóptico: as mesas foram viradas e agora são muitos os que observam poucos ${ }^{14}$.

Da confluência do pan-óptico (o suporte televisão vigiando e avaliando telespectadores) com o sinóptico (telespectadores interferindo nas tramas), criou-se um modelo próximo do interativo no desenvolvimento das telenovelas. Na citada América, além do beijo gay que não houve, registrou-se uma troca nos pares românticos, insinuados no início. As personagens Tião (interpretado por Murilo Benício) e Sol (vivida por Deborah Secco) não viveram seu final feliz, pois o público preferiu vê-lo casado com Simone (Gabriela Duarte) e ela, com Ed (Caco Ciocler).

Inversão semelhante havia acontecido em Senhora do Destino ${ }^{15}$, antecessora de América, no principal horário de novelas da Globo. Maria do Carmo (Suzana Vieira), no plano inicial do autor Aguinaldo Silva, terminaria com Dirceu (José Mayer), mas a empatia do público com Giovanni (José Wilker) o fez vencedor na disputa do amor da personagem principal.

Em Como Uma Onda ${ }^{16}$ (exibida pela TV Globo na faixa das 18 horas), Amarante (personagem de Kadu Moliterno) foi ressuscitado por exigência dos telespectadores. Já Começar de Novo ${ }^{17}$ (também da Globo, mas na faixa das 19 horas) teve mudança radical no caráter do herói, interpretado por Marcos Paulo. Baseado no célebre Conde de Monte Cristo, de Alexandre Dumas, ele teve de abandonar sua sede de vingança e ficou completamente descaracterizado, porque o público não aceitou um herói que fazia outros sofrerem para punir os culpados por sua tragédia.

Para satisfazer esse novo telespectador, que deseja interferir nas tramas como se elas fossem reality-shows, a televisão facilitou o acesso dos demais meios aos lances futuros das novelas, criando uma estrutura de divulgação que incentiva a antecipação. O resumo dos capítulos veiculados nas edições dominicais dos jornais é distribuído na quartafeira para não atrasar os fechamentos dos suplementos e revistas. Fotos das cenas são liberadas para a internet quase simultaneamente às gravações e publicadas nos meios impressos do dia seguinte. A foto da queda do peão Tião em América foi disponibilizada na primeira semana de agosto de 2005, e só colocada no ar em novembro.

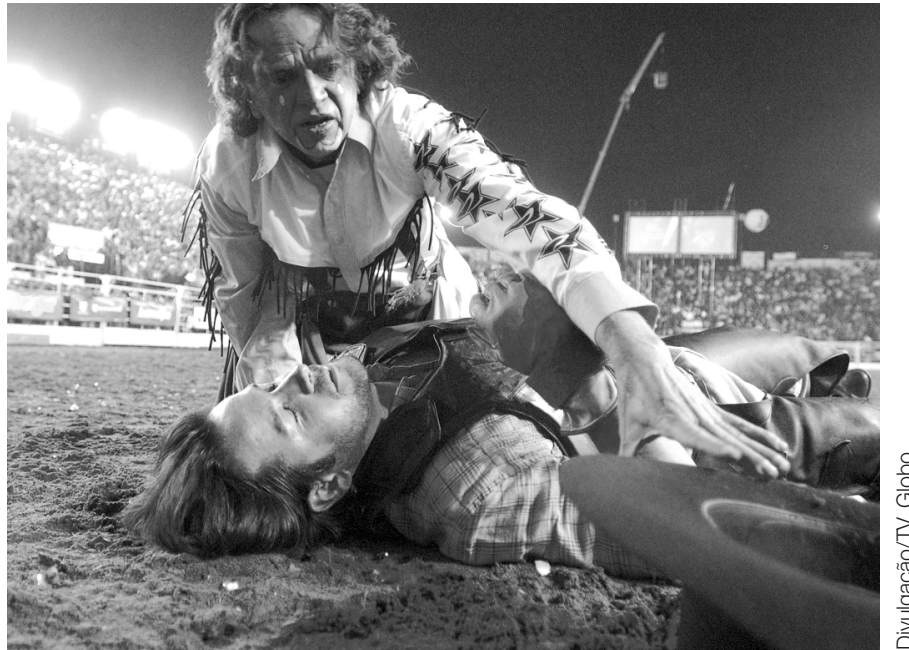

Lances futuros: A foto da queda de Tião (Murilo Benício) foi distribuída pela emissora para os meios de comunicação antes de a cena ir ao ar.
14. Ibid., p. 140-141.

15. De Aguinaldo Silva. Direção geral Wolf Maya, jun. 2004/mar. 2005

16. De Walter Negrão. Direção geral Denis Carvalho e Mauro Mendonça Filho, nov.2004/jun.2005

17. De Antônio Calmon e Elizabeth Jhin. Direção geral Carlos Araújo e Luiz Henrique Rios, ago. 2004/jun. 2005. 
comunicação \& educação • Ano XIII • Número 1 • jan/abr 2008

\section{A IMAGEM COMO ELEMENTO DE CONFIRMAÇÃO}

A postura, que poderia ser definida como contra-senso, de quem aceita assistir a telenovela sabendo o teor dos capítulos, foi tema de questão no seminário A Telenovela Além do Entretenimento, promovido pelo Núcleo de Pesquisa de Telenovela da ECA-USP, em 26 de agosto de 2005, na Escola de Comunicações e Artes da USP, no qual foram palestrantes o autor Lauro César Muniz, a dramaturga e professora Renata Pallottini e a professora Maria Aparecida Baccega. Na oportunidade, foram ressaltadas as características do suporte midiático televisão como elemento mediador de confirmação, com a professora Baccega lembrando que a telenovela é produto umbilicalmente ligado à imagem.

Na platéia do evento, Mauro Alencar, um dos principais pesquisadores da história da telenovela, recordou que o início dessa sinergia ficção/informação se deu com a publicação nos anos 1980, pela Folha de S. Paulo, de capítulos exibidos na noite anterior. Era um serviço ao leitor interessado na atração televisiva e impossibilitado de acompanhá-la. Na ordem então estabelecida (imagem/escrito) não havia o que se confirmar. Com a inversão da prática, o imagético assume o papel de confirmador do impresso.

Para Alencar, mesmo conhecendo detalhes dos episódios, o telespectador quer saber como tal ator interpretou a cena de choro ou como o diretor resolveu a seqüência de uma perseguição nas ruas. Na novela Mulheres Apaixonadas ${ }^{18}$ (TV Globo), a cena da morte da personagem Fernanda, vivida por Vanessa Gerbelli, foi destacada em primeira página por vários jornais e, mesmo assim, foi recorde de audiência ao ser exibida.

Na linha da confirmação, verifica-se nesse fenômeno de comunicação uma relação de desconfiança, a qual Freitas chama de esquema básico da comunicação "emissor-mensagem-receptor"19. O emissor que vai repassar a informação dos suportes midiáticos não confia no conteúdo da mensagem. Por isso, a jovem (emissor) que diz à colega de trabalho (receptor) que "fulano vai beijar fulana, na novela tal" (mensagem), porque ela viu no jornal ou na internet, precisa sentar-se em frente à TV e ver o beijo para poder orgulhar-se de deter a informação. Já o receptor precisa auferir se o emissor detinha realmente a informação. Vale dizer: quem, no escritório, ouviu a antecipação assiste ao beijo para confirmar o conhecimento da amiga. Assim, o receptor valida a mensagem e adere à nova forma de acompanhar as telenovelas, permitindo a conclusão de que os meios envolvidos ajudam-se reciprocamente.

18. De Manoel Carlos. Direção geral Ricardo Waddington, Rogério Gomes e José Luis Villamarin, fev./out. 2003.

19. FREITAS, op. cit., p. 13.

\section{DIA DE SUSPENSE EXIGE NOITE SEM SURPRESAS}

Uma mudança importante no cenário econômico brasileiro também contribuiu para a validação da desconstrução do suspense nas telenovelas. $\mathrm{Na}$ época em esse produto se consolidou como elemento da cultura de massa, a 
grande maioria dos telespectadores era formada por mulheres que não necessitavam trabalhar fora. O fim do chamado milagre econômico e o achatamento do poder aquisitivo dos brasileiros nas décadas de 1980 e 1990 fizeram com que a mulher se dedicasse à dupla jornada, ajudando no pagamento das despesas e cuidando da casa. Muitas acabam assistindo a capítulos de relance enquanto preparam o jantar e desempenham outras tarefas domésticas. O conhecimento prévio do desenrolar do enredo lhe permite não perder o sentido das ações.

Outro componente que justifica o interesse pelo não-suspense é a dinâmica estressante dos dias atuais, com um mercado de trabalho altamente competitivo e uma insegurança cada vez maior nas grandes cidades. Martín-Barbero lembra: "Se a televisão atrai é porque as ruas expulsam; é dos medos que vivem as mídias"20. Delimitando a análise ao cenário da capital paulista, temos um telespectador que sai de casa sem saber se terá lugar no ônibus, no metrô ou no trem lotado, ou quanto tempo de congestionamento vai enfrentar. Ele não pode preocupar-se com os contratempos e perigos encarados pelos habitantes do mundo imaginário das telenovelas.

Além disso, ele sabe que os problemas do ficcional sempre se solucionam. Como nota Bauman:

[...] a vida desejada tende a ser a vida vista na TV. A vida na telinha diminui e tira o charme da vida vivida: é a vida vivida que parece irreal, e continuará a parecer irreal enquanto não for remodelada na forma de imagens que possam aparecer na tela ${ }^{21}$.

Assim a convivência sem sustos entre ficção e realidade, garantida pelo saber antes, facilita o cumprimento da obrigação, explicitada no campo do inconsciente, de também se viver o mundo imaginário. Esse compromisso é gerado pelo que Certeau chamou de "a força inercial do hábito" ${ }^{22}$ e pela capacidade de a telenovela atingir uma simbiose perfeita entre telespectador e personagem.

Vera da Rocha Resende assinala:

[...] o espectador é induzido, e até pressionado a assimilar opiniões dos personagens, a ver o objeto do modo como eles o vêem, a localizar-se na trama, [...] a sensação é que os personagens das telenovelas são criaturas reais que lutam e que alcançam o que a grande maioria gostaria de ser ou de alcançar. Noticiários, jornais e revistas de grande circulação noticiam os episódios das telenovelas em manchetes. Os personagens ganham vida real ${ }^{23}$.

Márcia Gomes reforça tal impressão de simbiose ao mostrar como os receptores da telenovela analisam a influência recebida:

[...] Para as mulheres entrevistadas, as telenovelas têm o poder e possuem os meios para influenciar as pessoas que as assistem. Exercem influência porque o que elas apresentam é utilizado pelos telespectadores que, segundo elas, reproduzem e repetem (ações, comportamentos, atitudes etc.) o que vêem nesses programas $^{24}$.
20. MARTÍN-BARBERO: REY, op. cit., p. 40.

21. BAUMAN, op. cit., p. 99.

22. CERTEAU, Michel de; GIARD, Luce; MAYOL, Pierre. Tradução de Ephraim F. Alves e Lucia Endilich Orth. A invenção do cotidiano 2: morar, cozinhar. Petrópolis: Vozes, 1996. p. 85.

23. RESENDE, Vera da Rocha. A vida em capítulos. In: DOWBOR, Ladislau (Org.). Desafios da comunicação. 2. ed. Petrópolis: Vozes, 2000

24. GOMES, Márcia. A leitura interpretativa das telenovelas. VI Congreso Latinoamericano de Investigadores de la Comunicación (ALAIC), Santa Cruz de la Sierra, Bolívia, 2002. 
comunicação \& educação • Ano XIII • Número 1 • jan/abr 2008

Também para quem deseja estar informado sobre as origens de determinado comportamento ou de uma nova expressão incorporada aos diálogos do dia-a-dia, é importante ter informações sobre quem está ocupando a tela. Quando um bordão criado no ficcional se incorpora ao falar da realidade, ele vence as limitações diatópicas, diastráticas e diafásicas da linguagem, criando a necessidade em quem o ouve e deseja repeti-lo ou criticá-lo de saber em que contexto é usado. Neste caso, a quem não acompanha a telenovela em que o bordão surgiu, resta a saída de informar-se em outros suportes.

\section{DISSEMINAÇÃO DA INFORMAÇÃO PERMITE ATINGIR MAIORIA}

Uma estimativa do número de pessoas que têm acesso à antecipação dos capítulos e se tornam disseminadoras do saber antes, é possível a partir das tiragens e dos níveis de audiência dos veículos envolvidos. A circulação nacional média dos jornais, com sede na Grande São Paulo, que publicam o resumo das novelas aos domingos é: Folha de S. Paulo: 377.622; Estado de S. Paulo: 306.448; Diário de S. Paulo: 91.233; Jornal da Tarde: 46.256, segundo dados do Instituto Verificador de Circulação - IVC de maio de 2005. O Diário do Grande ABC tem tiragem de 57.885, informa seu departamento comercial. O Agora SP (tiragem média de 78.155 em setembro/2004, segundo o IVC) traz a informação diariamente. Uma pesquisa do Instituto Gallup, publicada em junho de 1988 pela Revista Imprensa, mostrou que a seção Variedades dos jornais paulistanos era a preferida por $24,3 \%$ dos leitores, enquanto $7,3 \%$ deles nunca a liam.

A circulação nacional das revistas que exploram esse nicho atinge: Contigo: 126.090, Minha Novela: 73.330 e Tititi: 82.700, também segundo o IVC. Além destes títulos da Editora Abril, estão nas bancas, com resumo das tramas, as revistas Chega Mais (tiragem de 130 mil) e Amiga (70 mil), da Editora Símbolo, e TV Brasil (60 mil) e Conta Mais (60 mil), da Editora Escala. Os números são dos respectivos departamentos comerciais. Na internet, os portais UOL, IG, Terra e Globo são alguns dos que oferecem atalhos que levam aos capítulos das novelas e geralmente colocam chamadas em suas páginas principais. A audiência da Rádio Globo AM, pela manhã, quando o apresentador Leão Lobo conta o que vai acontecer nas novelas à noite, é de 144.052 ouvintes por minuto (Ibope de junho de 2005), enquanto o programa Mulheres, da TV Gazeta, que revela os capítulos todas as tardes, atinge 65 mil telespectadores (Ibope da semana de 28/8/2005 a 4/9/2005).

Esse amplo leque de fontes, aliado ao poder multiplicador que esta informação alcança, por ser considerado valioso por seus detentores, permite afirmar, a partir da audiência de $53 \%$ da novela América, da TV Globo - o equivalente a 4.253 milhões de pessoas na Grande São Paulo (Ibope de 22/8/2005 a 29/8/2005) -, que a grande maioria dos telespectadores tem conhecimento de como se desenrolará o capítulo quando se posiciona para assisti-lo e validam a prática da antecipação. Por outro lado, o elevado índice de audiência nos 


\section{A desconstrução do suspense na telenovela - Luiz Antonio de Paula}

horários dedicados a esse tipo de ficção e o significativo número de publicações que veiculam seu conteúdo provam que a sinergia traz bons resultados para todos os suportes midiáticos envolvidos no fenômeno.

Resumo: Partindo da constatação de que grande parte do público brasileiro que assiste a telenovelas senta-se diante da TV já sabendo o que vai acontecer durante os capítulos, este artigo analisa a sinergia possível entre os vários suportes midiáticos. Para explicar o fenômeno de comunicação revelado na aceitação da quebra do suspense, que é característica deste produto televisivo, o estudo destaca a valorização do poder de ter a informação e o perfil do novo telespectador, fruto de uma realidade urbana, em que as ansiedades e dúvidas no campo real não lhe permitem dedicar-se a incertezas da ficção.

Palavras-chaves: comunicação, telenovela, sinergia intermeios, informação e suspense.
Abstract: Starting from the verification that great part of Brazilian TV soap operas attendees sits down before the TV devices already knowing what will happen during the chapters, this article analyzes the possible synergy among the several media ways. To explain the communication phenomenon revealed in the acceptance of the break of the suspense, which is characteristic of this TV product, the study highlights the valorization of the power of having the information and the new viewer's profile, as a product of an urban reality, where the anxieties and doubts in the real don't allow to dedicate to uncertainties of the fiction.

Keywords: Communication, soap opera, synergy among media, information and suspense. 


\section{Experiências de Deus e nossas complexas relações com Ele}

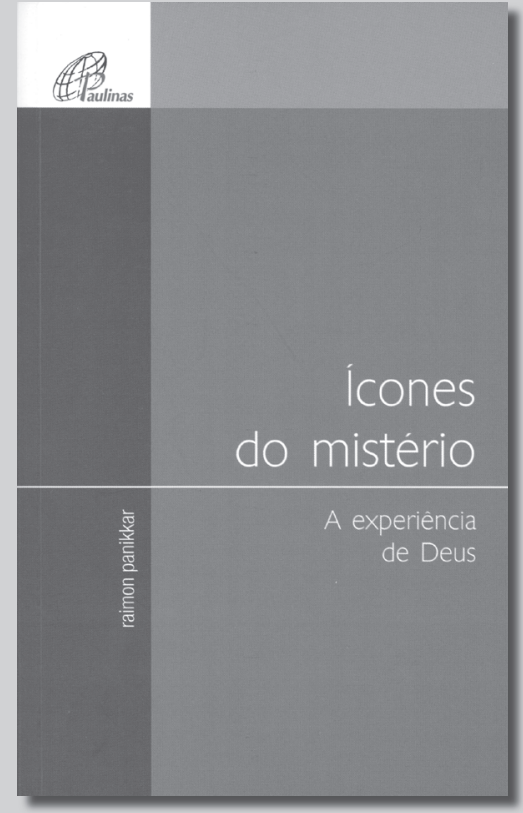

Reflexão acerca do mergulho que hoje as pessoas fazem em suas atividades rotineiras em detrimento dos exercícios do espírito, esta obra ressalta o questionamento que todo "coração puro" deve fazer de sua vivência humana diante da vida divina. Resultado da revisão de uma semana de palestras que 0 escritor Raimon Panikkar proferiu na abadia beneditina espanhola de Silos, a obra destaca a complexa relação entre Deus e o ser humano e analisa 0 papel das religiões como intermediárias entre 0 Criador e suas criaturas.

\section{- Ícones do mistério •}

A experiência de Deus

Autor: Raimon Panikkar

Páginas: 256

ISBN: 9788535619102
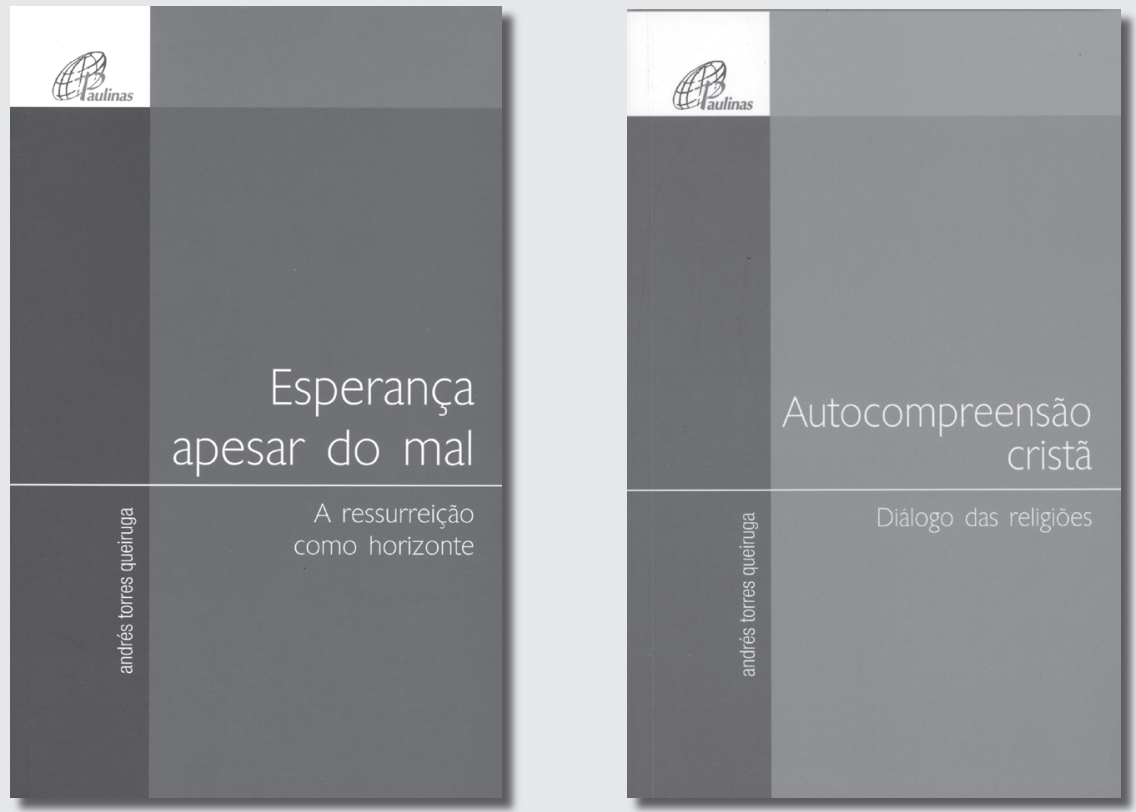

A esperança é um mistério. Durante séculos, esteve restrita ao tratado moral das virtudes, mas se converteu em preocupação primordial hoje. Mas como reler criticamente a seqüência mítica paraíso-queda-castigo-redenção sem sustentar efeitos devastadores? Como confrontála com a terrível experiência do mal, mostrando a atualidade e o valor da promessa da ressurreição? Para tentar entendê-la, Queiruga apresenta uma proposta que reafirma a esperança cristã como muito mais que mera especulação.

\section{- Esperança apesar do mal •}

A ressurreição como horizonte

Autor: Andrés Torres Queiruga

Páginas: 184

ISBN: 9788535618891
Queiruga trata do relacionamento entre as religiões colocadas hoje em confronto direto, em virtude da mundialização da cultura, na era das comunicações simultâneas. Parte de uma renovada concepção da revelação como a forma de Deus se manifestar na vida dos humanos, e vai em busca da compreensão do que isso significa nesse contexto mundializado. A seu ver, só partilhando aquilo que crêem ser o melhor, num diálogo repleto de respeito e sempre disposto a dar e receber, as religiões podem ir se aproximando da inesgotável riqueza do mistério.

- Autocompreensão cristã • Diálogo das religiões

Autor: Andrés Torres Queiruga

Páginas: 216

ISBN: 9788535620559

\section{À venda na Rede Paulinas de Livrarias Se preferir, ligue 08007010081 ou acesse www.paulinas.org.br}

